\title{
VIISI TEESIÄ VILJELYKIERTOJEN OPPIMISESTA LUONNONMUKAISESSA VIHANNESVILJELYSSÄ
}

\author{
Laura Seppänen \\ Helsingin yliopisto, Maaseudun tutkimus- ja koulutuskeskus, Mikkeli
}

Osoite:

Toiminnan teorian ja kehittävän työntutkimuksen yksikkö

PL 47

000140 Helsingin yliopisto

puh.09-1914779

laura.seppanen@helsinki.fi

\section{Johdanto}

Viljelykierto eli kasvinvuorotus lienee yhtä vanha kuin maatalous. Tautiriskien välttämisen lisäksi viljelykierto tarjoaa ennaltaehkäiseviä keinoja ravinnehuoltoon, rikkakasvien torjuntaan ja maan rakenteen ylläpitämiseen. Luonnonmukaisessa maa- ja puutarhataloudessa viljelykierrolla on erityisen tärkeä merkitys.

Viljelykiertojen suunnittelu ja toteutus ei kuitenkaan ole helppoa. Ollakseen toimiva viljelykiertosuunnitelman tulee kytkeä hyödyllisellä tavalla viljelytoiminnan eri osa-alueet toisiinsa. Viljelykierron tulisi pitkällä tähtäyksellä taata viljelyn jatkuvuus myös nykyisissä muuttuvissa olosuhteissa, mutta olla myös kannattava lyhyellä aikavälillä. Hyvä kasvinvuorotus vaatii kokonaisvaltaista suunnittelua.

Mikään erikoistunut maataloustieteen ala ei yksin kykene huomioimaan kaikkia viljelykierron suunnittelussa tarvittavia näkökulmia. Tarvitaan muita lähestymistapoja. Jotta luomuvihannesviljelyn viljelykiertoihin liittyvää suunnittelua, toteutusta ja valvontaa kyettäisiin entistä paremmin ymmärtämään ja kehittämään, viljelykiertoja on tässä esityksessä tutkittu aivan uudella tavalla: käytännön luomuvihannesviljelytoiminnan ja siinä tapahtuvan muutoksen kautta.

\section{Tutkimuksen aineisto ja lähestymistapa}

Esitys perustuu tekijän väitöskirjatutkimukseen (Seppänen, painossa). Laadullinen tutkimusaineisto on kerätty vuosina 1997-1999 kahden luomuvihannestilan toiminnasta ja niiden viljelykiertojen suunnitteluista ja luomutarkastuksista.

Tutkimuksen lähestymistapa pohjautuu kulttuurihistorialliseen toiminnan teoriaan (Engeström, 1987; Seppänen, 2002). Viljelykierto käsitetään osana tavoitteellista ja systeemistä viljelytoimintaa. Toiminnan kohde on sekä reaalinen annettu että toimijoiden rakentama, ja se sisältää toiminnan motiivin. Tutkimuksessa on oletettu, että viljelykierto viljelytoiminnan eräänä organisointitasona on niin merkittävä, että se heijastaa viljelijöiden koko toiminnan kohdetta (Seppänen, 2000). Viljelykierto muotoutuu viljelyn lisäksi yhteistyössä muiden toimintojen, kuten neuvonnan ja luomutarkastusten, kanssa. Tällä yhteistyöllä on omat välineensä ja sääntönsä, jotka nekin muuttuvat ajan myötä.

\section{Viisi teesiä}

Tutkimuksiin pohjautuen alla esitetään viisi teesiä, jotka antavat näkökulmia monimutkaisen viljelykierron oppimiseen ja sen yhteistoiminnallisen suunnittelun ja valvonnan kehittämiseen. 


\section{Teesi 1: Viljelykierto - sääntö ja väline}

Viljelykierto ei ole viljelijöiden kannalta itseisarvo sinänsä, vaan sen tarkoituksena on palvella niitä tavoitteita, joita viljelijät, luomutuotanto ja yhteiskunta asettavat viljelylle ja pellon käytölle. Joskus luomuvihannesviljelijät voivat kokea viljelykierron toimintaansa hankaloittavana määräyksenä tai sääntönä. Tämä johtuu siitä, että viljelykierrolla on luomutuotannossa (ja myös ympäristötuen perusehdoissa) institutionaalinen rooli. Karjattoman luomuvihannestuotannon viljelykiertoon liittyvä perusristiriita on valinta kannattavien myyntikasvien ja muiden ei-kannattavien kasvien, kuten viherlannoitusten, välillä. Hyvä ratkaisu tähän olisi paikallinen yhteistyö karjatilojen kanssa, joka valitettavasti ei usein ole mahdollista. Kannattavuuteen voidaan vaikuttaa monin tavoin, esimerkiksi parantamalla vihanneslohkojen satotasoja.

Viljelijöiden oman viljelykierron ja sen muuttamisen hallinnan kautta viljelykierto voi muuttua rajoittavasta säännöstä viljelytoimintaa helpottavaksi välineeksi (Engeström ym. 2003). Sen institutionaalinen, sääntömäinen valvontakin voidaan ymmärtää tavaksi, jonka avulla kaukanakin olevat asiakkaat voivat vakuuttua luonnonmukaisen tuotannon laadukkuudesta.

Se, millä tavoin eri viljelyn osa-alueet otetaan huomioon luomutilan viljelykierrossa riippuu siitä, millainen viljelijöiden kohde on. Näin ollen hyvät viljelykierrolliset ratkaisut eivät johdu vain vallitsevista pelto- ja markkinaolosuhteista. Niihin vaikuttavat myös se, miten viljelijöiden kohde on rakentunut ajan myötä. Luomuvihannestoiminnan kohteiden erilaisuus tulee osin ymmärrettäväksi tilojen tuotantohistorioiden kautta. Esimerkiksi entisellä tavanomaisella karjatilalla on viljelykierron suhteen erilaiset oppimisen haasteet kuin entisellä kauppapuutarhalla (Seppänen, 2000).

\section{Teesi 2: Huomio ylivuotiseen viljelyyn ja nopeaan reagointiin.}

Viljelykiertojen oppimisen haaste on hahmottaa pellonkäyttö yli vuosien tapahtuvana pitkän tähtäyksen toimintana (Seppänen \& Koskimies, 2002). Tätä kutsutaan viljelykierron ylivuotiseksi haasteeksi. Esimerkiksi valitessaan viljelykasveja luomuviljelijän täytyy aina katsoa vähintään yhden kasvukauden yli, kun taas tavanomaisessa tuotannossa nämä ratkaisut voidaan helpommin tehdä vain yhtä vuotta ajatellen. Se on haaste erikoisesti silloin kun tilan historia on tavanomaisissa yhden vuoden sykliin perustuvissa tuotantosuunnissa, kuten vihannes- tai viljanviljelyssä. Ylivuotinen viljelyn haaste on ajallisesti pitkäkestoisempi kuin siirtymävaihe. Kestävä luonnonvarojen käyttö ohjaa ylivuotiseen viljelyyn.

Ylivuotisen, viljelykierron edellyttämän pitkän aikavälin oppimisen ohella luonnonmukaisessa vihannestuotannossa jatkuva tarkkailu ja ennakoiminen ovat tärkeitä. Monivuotinen suunnitelma ja ylivuotinen näkökulma eivät yksin riitä: viljelykierron onnistumiseksi on kyettävä joustavasti reagoimaan muutoksiin (Engeström ym. 2003). Yhtä tärkeää kuin huolellinen viljelykierron suunnittelu on myös kyetä nopeasti muuttamaan sitä. Viljelytoiminta elää jatkuvassa muutoksessa. Muutoksen hallinta tulisi kyetä huomioimaan viljelykiertojen suunnittelussa, toteutuksessa ja valvonnassa. Viljelykierto tulisikin ennemmin nähdä ajallisesti muuttuvana ja toimivana kuin lukkoonlyötynä. Tämä ei tee pitkän tähtäyksen suunnittelua tarpeettomaksi.

\section{Teesi 3: Huomio viljelyn, neuvonnan ja tarkastuksen yhteistyöhön.}

Viljelijöiden on mahdollista ja usein hyödyllistä käyttää luomuneuvojien apua viljelykiertojen suunnittelussa. Lisäksi luomutarkastajat valvovat tilojen viljelykiertoja. Kukaan näistä osapuolista ei välttämättä yksin pysty määrittämään, mikä on tietylle luomuvihannestilalle sopiva viljelykierto. Jos viljelykierto nähdään ajallisesti kehittyvänä muuttuvien olosuhteiden myötä, yhteistyö viljelijöiden, neuvojien ja viranomaisten välillä on välttämätöntä. Yhteistyön tulisi olla sellaista, että se mahdollistaa joustavuuden ja edistää uusien, innovatiivisten viljelykiertoratkaisujen kokeilemista ja leviämistä. Tämä yhteistyö edellyttää joustavuutta myös eri osapuolien välisessä työnjaossa (Seppänen \& Helenius, painossa). 
Teesi 4: Huomio viljelykierron suunnittelun yhteistoiminnallisiin välineisiin.

Viljelykiertojen suunnittelussa käytetään monenlaisia välineitä, kuten tukihakemuslomakkeita, ATKohjelmia, karttoja jne. Samoin luomutarkastuksessa käytetään omia lomakkeitaan. Tiloilla tai muissa tapaamisissa toteutuvat viljelykierron suunnittelu ja luomutarkastukset ovat yhteistoiminnallisia tapahtumia, jolloin hyvä kommunikaatio ja yhteinen asioiden ymmärtäminen vähentävät väärinkäsityksiä. Tämän takia tulisi edistää sellaisia viljelykierron ja suunnittelun välineitä, jotka voisivat olla samanaikaisesti kaikkien läsnä olevien nähtävillä (Seppänen \& Helenius, painossa).

Se, millä tavoin viljelykierto on esillä näiden lomakkeiden ja välineiden avulla vaikuttaa siihen, miten viljelykierto käsitetään. Kasvinvuorotuksesta on yleensä kaksi erilaista esittämisen tapaa eli representaatiota. Ensimmäinen on taulukko, jossa eri peltolohkojen viljelykasvit on suunniteltu viideksi vuodeksi eteenpäin. Tämä on tarkka tapa, jota käytettäessä tulee kiinnittää huomiota siihen, kuinka sitä voidaan tarvittaessa joustavasti muuttaa. Toinen esittämisen tapa on karkeampi, eri vuosina toistuva kasvisekvenssi. Sen hyvänä puolena on yksinkertaisuus, mutta toisaalta sen käyttö esimerkiksi luomutarkastuksissa voi johtaa siihen, että viljelykierto jää erilleen siitä, mitä peltolohkoilla tapahtuu.

Kolmanneksi tulisi kiinnittää huomiota tiedon hankinnan välineisiin tiloilla tapahtuvien viljelykiertosuunnittelujen aikana (kuten internet-yhteys, puhelut, kirjallisuus jne).

Teesi 5: Huomio myös neuvonnan, tutkimuksen ja hallinnon oppimiseen.

Kasvinvuorotus on vanha uusi asia. Oppiminen viljelykierroissa ei ole pelkästään viljelijöiden, vaan myös neuvojien, tutkijoiden ja viranomaisten haaste. Monititeteisyys on viljelykiertojen tutkimisen ja kehittämisen keskiössä. Se, mitä viljelykierrossa pitää oppia, ei ole täysin ennalta määrätty tai ylhäältä annettu: viljelykierron kehittämisen suunta on eri muutostekijöistä johtuen avoin. Viljelykierron käytännöllistä ja yhteiskunnallista roolia määritetään jatkuvasti viljelytoiminnassa sekä eri toimijoiden välisessä yhteistyössä.

\section{Kirjallisuus}

Engeström, Y. 1987. Learning by expanding: an activity-theoretical approach to developmental research.Orienta-Konsultit, Helsinki.

Engeström, Y., Puonti, A. \& Seppänen, L. 2003. Spatial and temporal expansion of the object as a challenge for reorganizing work. In: Nicolini, D., Gherardi, S. \& Yanow, D. (Eds.). Knowing in organizations: A practice based approach. Armonk: M. E. Sharpe, p. 151-186.

Seppänen, L. 2000. Activity theoretical view on crop rotation planning in organic vegetable farming. Fourth European Symposium on European Farming and Rural Systems Research and Extension, in Volos, Greece, April 3 to 7, 2000. Proceedings: 283-292.

Seppänen, L. 2002. Creating tools for farmers' learning: an application of developmental work research. Agricultural Systems 73 (1): 129-145.

Seppänen, L. Painossa. Learning challenges in organic vegetable farming. Väitöskirjan käsikirjoitus. Ilmestyy helmikuussa 2004

Seppänen, L. \& Koskimies, H. 2002. Farming across the years: temporal and spatial dimensions in learning organic farming. IFSA European Symposium on Farming and Rural Systems Research and Extension: Local Identities and Globalisation. Florence, Italy, April 8 to 11, 2002. Proceedings: 528-537.

Seppänen, L. \& Helenius, J. Painossa. Do inspection practices in organic agriculture serve organic values? A case study from Finland. Accepted by Agriculture and Human Values, March, 2003. 